\title{
Analysis of chloride diffusivity in concrete containing red mud
}

\section{Análise da difusão de cloretos no concreto contendo lama vermelha}
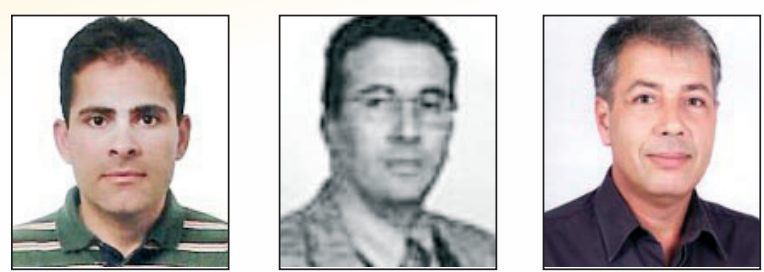

D.V. RIBEIRO a verasribeiro@hotmail.com

J.A. LABRINCHA ${ }^{b}$

jal@ua.pt

M.R. MORELLI ${ }^{c}$ morelli@power.br

\begin{abstract}
Red mud is a solid waste produced in the alumina production process and, due to its high $\mathrm{pH}$, is classified as hazardous. Its incorporation in concrete mixtures, acting as filler due to the particles fineness, might be an interesting reuse alternative. The focus of this paper is to study the chloride diffusivity of concrete mixtures containing red-mud. The concentration of chlorides was monitored by measuring the conductivity of the anolyte, which was distilled water initially. In addition, the estimation of the chloride ions diffusion coefficients in steady and non-steady conditions, Ds and Dns, was obtained from the "time-lag" and "equivalent time" between diffusion and migration experiments. Due to superfine particle-size distribution and the "filler" effect, the red mud addition seems to assure lower chloride diffusivity.
\end{abstract}

Keywords: concrete, red mud, chloride diffusion, corrosion.

\section{Resumo}

A lama vermelha é um resíduo sólido gerado no processo de produção de alumina e, devido a seu elevado pH, é considerado "perigoso". A característica de elevada alcalinidade associada à presença de aluminossilicatos facilitam a assimilação e formação de compostos pela reação com os íons cloreto. No presente estudo, a concentração de cloretos foi monitorada por meio da medida da condutividade do anólito, que inicialmente era água destilada. Adicionalmente, foram estimados os coeficientes de difusão nos estados estacionário e não-estacionário, obtidos através do "time lag" e do "tempo equivalente" de medida. Os resultados obtidos mostraram que a adição da lama vermelha é benéfica ao concreto, reduzindo a taxa migração dos cloretos (coeficientes de difusão) devido à elevada finura da lama vermelha (efeito filler) e à ação dos aluminossilicatos.

Palavras-chave: concreto, lama vermelha, difusão de cloretos, corrosão.

a Universidade Federal da Bahia, Departamento de Ciência e Tecnologia dos Materiais, verasribeiro@hotmail.com, Escola Politécnica - Rua Aristides Novis, 02, Federação, 40210-630. Salvador/BA, Brasil;

- Universidade de Aveiro, Departamento de Engenharia Cerâmica e do Vidro, jal@ua.pt, Campus Universitário de Santiago, 3810-193. Aveiro, Portugal; Universidade Federal de São Carlos, Departamento de Engenharia de Materiais, morelli@power.br, Rodovia Washington Luis, Km 235. $13566-550$. São Carlos/SP, Brasil. 


\section{Introduction}

The huge volumes of industrial waste produced today represent one of the world's greatest environmental problems, with an annual volume of up to 25 million tons of waste generated in São Paulo alone [1]. The red mud studied in the present paper is a by-product of aluminum production from bauxite ore produced by the Bayer process. The vast quantities of wastes call for the search for widely consumed target products into which they can be incorporated, such as civil construction.

The world's production of bauxite in 2009 was 205 million tons, and the main producing countries were Australia, China, Brazil, Guinea, India and Jamaica. Ranking third in worldwide production in 2009 , Brazil produced 26.6 million tons of bauxite. It also has the world's third largest bauxite ore reserves (around 3.5 billion tons), concentrated mainly in the northern part of the country (state of Pará) [2].

Roughly $0.3-1.0$ tons of red mud waste are generated per ton of aluminum produced. Brazil has discarded about 10.6 million tons/ year of caustic red mud in recent years and the worldwide generation of red mud exceeds 117 million tons/year [3].

Approximately $35-40 \%$ of bauxite ore is discarded in the form of strongly alkaline RM slurry [4]. This mud contains about $60 \mathrm{vol}$. \% of solid content in the form of superfine particles. Therefore, this material has a large surface área and a strong water absorbing capacity. Alkaline matrices such as those provided by Portland cement in mortars and concrete are commonly used in waste conditioning. They are inexpensive, have an extensively documented history of safe use, and are a draw-upon readily-accessible technology. Alkalinity greatly reduces the solubility of many hazardous inorganic species and inhibits microbiological processes. Moreover, since these matrices require water for hydration, they may readily incorporate wet wastes [5] such as red mud.

The search for an economically and environmentally viable alternative has led to the study of red mud for various applications, such as adsorbent for the removal of heavy metals from aqueous solutions [6], building materials such as bricks [7], ceramics and tiles [8], ceramic glazes [9], as polymer-based composites to replace wood [10], iron-rich cement [11, 12], component of clinker [4, 11, 12], and the addition to mortar and concrete formulations was also reported [13]. The use as common building material has been suggested as an alternative that ensures high rates of consumption [14].

It is widely known that chloride ions cause local breakdown of the passive layer and subsequent corrosion of reinforcing steel bars (rebars) in concrete structures.

Several studies $[15,16,17]$ report the use of migration tests to evaluate the resistance of concrete to penetrating chloride ions. Initially, these tests were used to evaluate this penetration based on the total penetrated load, according to the ASTM C 1202/1992 standard, and to estimate the diffusion coefficient in steady-state conditions, as suggested by ANDRADE [15]. More recently, several authors have used migration tests to calculate the diffusion coefficient in nonsteady-state conditions [16, 17]. Depending on the proposed objective, these tests may vary in terms of procedure and parameters, but all are based on the induction of the movement of ions under the action of an external electric field [18]

The migration test is based on the principle of applying a potential difference between two cells: one containing a chloride solu- tion (cathode) and the other without chlorides (anode), which are placed on each side of the concrete sample under analysis. The externally applied electric potential forces the passage of chloride ions through the concrete sample from the first (cathode) to the second (anode) cell. By this method, the passage of chloride ions through the specimen is induced by the electric current generated by the potential difference of 12 volts applied to a direct current source through the electrodes contained in each cell.

The positive cell (anode) is filled with distilled water to prevent corrosion-induced deposition of chlorides. The negative cell (cathode) is composed of a solution containing a concentration of $1 \mathrm{M}$ of sodium chloride $(\mathrm{NaCl})$.

\section{Materials and methods}

\subsection{Materials}

Ordinary CP-II 32 Z Portland cement (OPC), according to the Brazilian NBR 11578 standard, commercially available in São Carlos, Brazil, was selected as reference in all the tests. The coarse aggregate was dense, crushed granitic stone and the sand was supplied from a river deposit commercially available in São Carlos, Brazil.

The red mud came from Poços de Caldas-MG and was supplied by ALCOA Brazil. It is a mixture containing about $60 \%$ of solids, collected immediately after alumina recovery from the digestion process.

\subsection{Methods}

\subsubsection{Materials characterization and Concrete Dosage}

The materials characterization involved $X$-ray diffraction (Rigaku Geirgeflex ME 210GF2 Diffractometer) and X-ray fluorescence (Philips PW1480 X-ray Fluorescence Spectrometer) analyses, while physical parameters such as the specific surface area (estimated by BET, using a Micrometrics Gemini 2370 V1.02 equipment) and specific gravity (Helium Pycnometer Accupyc 1330 V2.01 from Micrometrics) were also determined. Similar determinations were performed on sand and on the red mud.

The concrete formulation used as reference was prepared in a $1.0: 1.5: 1.3: 0.5$ (Portland cement + red mud : sand : coarse aggregate : water) weight ratio. The mortar content was $65.8 \%$ and the cement consumption was $540 \mathrm{~kg} / \mathrm{m}^{3}$ compared to a reference mixture. Distinct concrete mixtures in which cement was partially replaced by red mud $(10,20$, and $30 \%$ in weight) were analyzed. All the specimens were cylindrical. To perform the migration tests, specimens of $50 \mathrm{~mm}$ in diameter and $100 \mathrm{~mm}$ in length were molded, from which $40 \mathrm{~mm}$ thick slices were cut, discarding the outer top and bottom parts in order to minimize heterogeneities and ensure water saturation.

\subsubsection{Chloride Migration Testing}

The American ASTM C-1202/97 standard (Standard Test Method for Electrical Indication of Concretes Ability to Resist Chloride Ion Penetration) advocates the use of vacuum saturated samples before submission to migration tests. This procedure has been adopted by other researchers $[11,16]$ o ensure that the penetration of chlorides into the sample was caused predominantly by diffusion. In this work, vacuum saturation was not used; instead, the samples 


\section{Figure 1 - (A) Layout and assembly of the chloride migration test; (B) Chloride migration test apparatus}
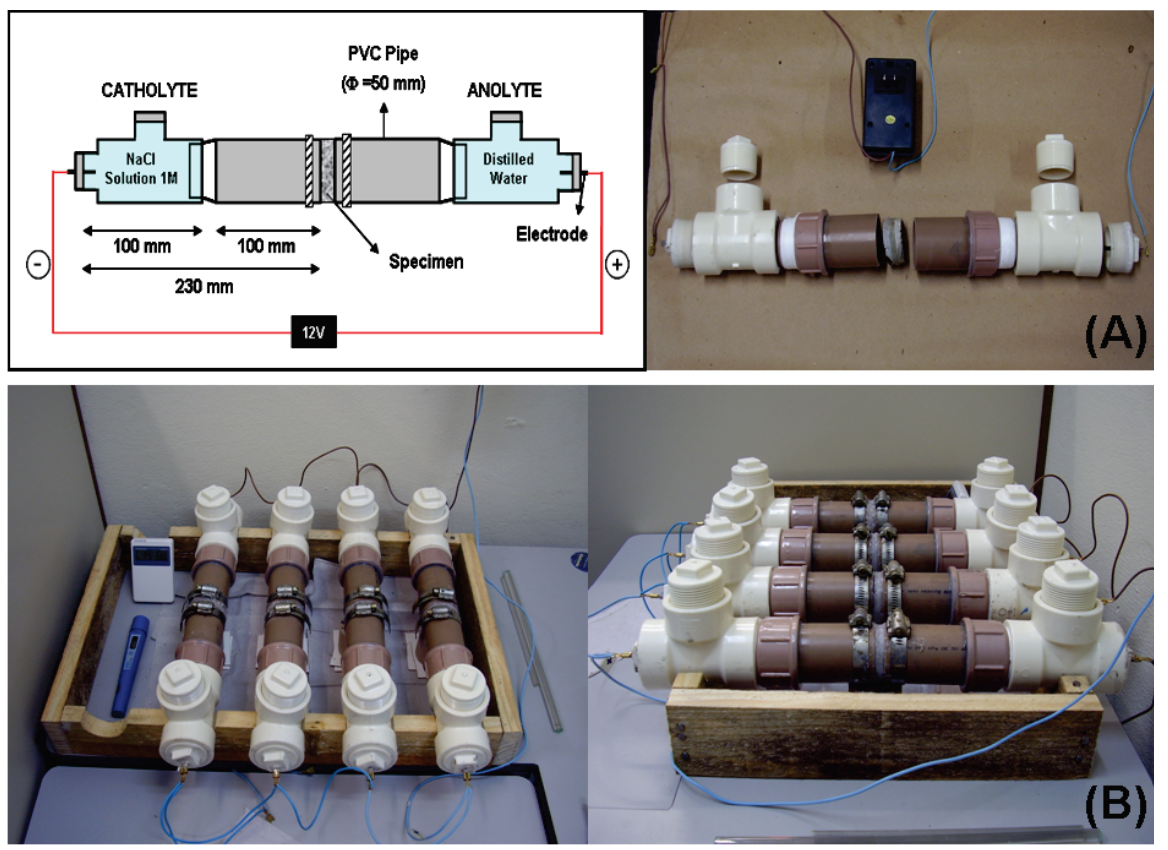

were soaked in water for 24 hours prior to testing, according to SANTOS [18] studies.

PVC cells were used, consisting of a $50 \mathrm{~mm}$ diameter "T" tube with a top cover for output measurements and a side containing the electrode, properly sealed to prevent loss of solution. The specimens were placed at the interface between the two chambers, and were also glued with a silicone-based adhesive. Thus, the ion exchange between cells took place only through the body surfaceto-test exposed area. The test setup and its implementation are illustrated in Figures 1a and 1b, respectively. A 12-Volt current was applied to the system by means of electrodes positioned at the ends of the cell, which were connected to copper wires from a controlled voltage source.

The concentration of chlorides in the anolyte chamber (initially free of chlorides) was analyzed at regular intervals during the experiment using a portable digital conductivitimeter (CD-880, Instrutemp). The chloride concentration was estimated based on the correlation between this parameter and the electrical conductivity, as indicated in Figure 2. Conductivity values were referenced to a temperature of $25^{\circ} \mathrm{C}$, by considering an increase of $2 \%$ in the conductivity of the solution when the temperature rose by one degree centigrade.

\section{Results and discussion}

\subsection{Caracterização das matérias-primas}

The Portland cement used in this work has a specific surface area $0.93 \mathrm{~m}^{2} / \mathrm{g}$ and its specific gravity is $3.11 \mathrm{Kg} / \mathrm{dm}^{3}$. The sand has a specific surface area of $0.68 \mathrm{~m}^{2} / \mathrm{g}$ and its specific gravity is 2.70 $\mathrm{Kg} / \mathrm{dm}^{3}$. According to Brazilian NBR 7211 standard, it is classified as fine sand. The gravel has a specific gravity of $2.74 \mathrm{~kg} / \mathrm{dm}^{3}$ and maximum dimension of $19 \mathrm{~mm}$.

The red mud was received in the form of a paste containing about $40 \%$ free water. In the present study, the material was dried and crushed, and then used as a powdered additive. Ideally, if its potential as a constituent of concrete is confirmed, red mud should be incorporated and tested in the as-received condition, and the free water present in the mud should be considered a component of the mortar mix.

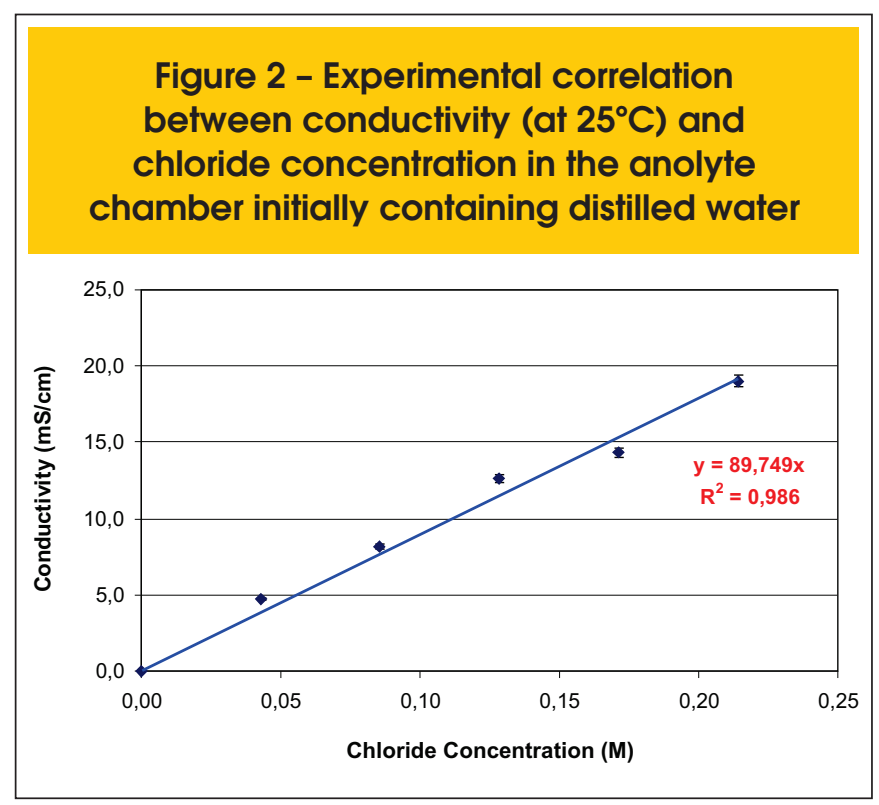


Table 1 - Chemical composition of red mud estimated by XRF

\begin{tabular}{lcccccccccc} 
Component & $\mathrm{Al}_{2} \mathrm{O}_{3}$ & $\mathrm{Fe}_{2} \mathrm{O}_{3}$ & $\mathrm{Na}_{2} \mathrm{O}$ & $\mathrm{CaO}$ & $\mathrm{SiO}_{2}$ & $\mathrm{~K}_{2} \mathrm{O}$ & $\mathrm{MnO}$ & $\mathrm{TiO}_{2}$ & Others & LOl $^{\circ}$ \\
Content (wt.) \% & 19.87 & 19.85 & 7.35 & 4.61 & 14.34 & 1.87 & 0.21 & 2.66 & 1.01 & 27.20 \\
\hline LOI = Loss on ignition & & & & & & & & & & \\
\hline
\end{tabular}

The specific surface area of bauxite waste is $20.27 \mathrm{~m}^{2} / \mathrm{g}$, the specific gravity is $2.90 \mathrm{~kg} / \mathrm{dm}^{3}$ and the $\mathrm{pH}$ is very high (12.95), exceeding the limit (12.5) for non-hazardous wastes established by the Brazilian NBR 10004 standard.

Table 1 gives the chemical composition of the waste, while Figure 3 shows the corresponding XRD pattern. As expected, aluminium hydroxide $\left(\mathrm{Al}(\mathrm{OH})_{3}\right)$, calcium carbonate $\left(\mathrm{CaCO}_{3}\right)$, and iron oxide $\left(\mathrm{Fe}_{2} \mathrm{O}_{3}\right)$ are the predominant components, but the relative amounts of $\mathrm{SiO}_{2}$, muscovite, $\mathrm{FeO}(\mathrm{OH})$ and $\mathrm{Na}_{2} \mathrm{O}$ (or $\mathrm{NaOH}$ ) are also relevant. Some of these oxides were also detected by $\mathrm{XRD}$, in addition to aluminum hydroxide and a complex $\mathrm{Na}_{5} \mathrm{Al}_{3} \mathrm{CSi}_{3} \mathrm{O}_{15}$ phase.

\subsection{Ensaio de migração de cloretos}

Figure 4 shows the evolution of chloride concentration in the anolyte chamber during migration tests. Four samples were used for each addition content and the results presented are the mean values obtained with their standard deviations. As expected, $\mathrm{Cl}^{-}$concentration increases with time once the voltage is applied, following the predictable trend.

Initially, there is a period in which the amount of chlorides passing into the anolyte chamber is negligible. Its duration corresponds to the so-called "time lag" ( $t$ ), and can be defined as the time required for chlorides to pass through the concrete disc, causing its saturation. This period of time will later serve as the basis for estimating the $D_{n s}$ values. After this period, the flux of chloride ions through the specimen becomes constant, which corresponds to the steadystate period.

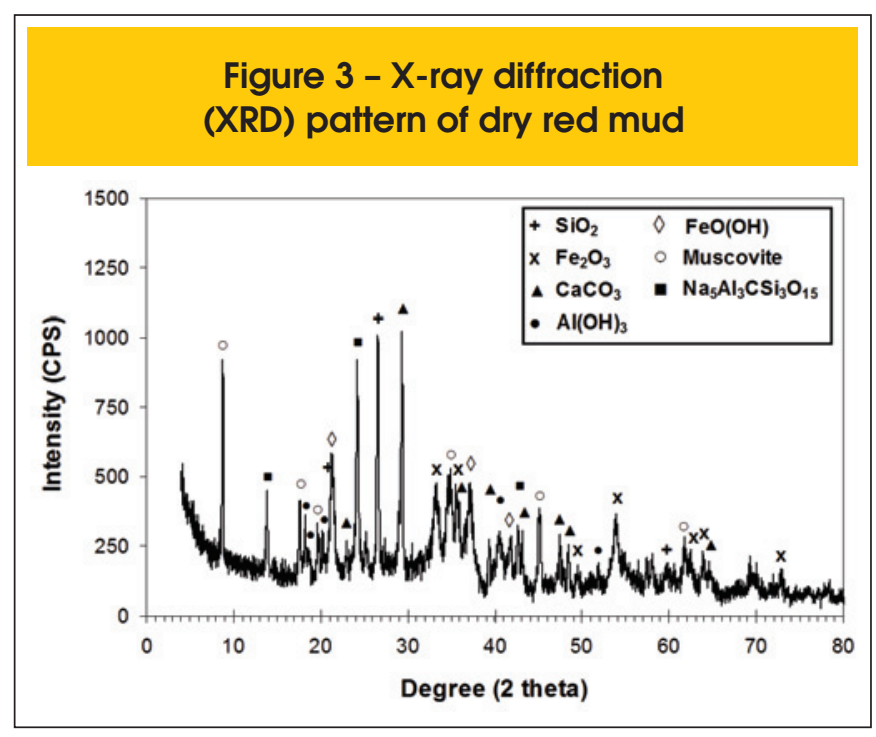

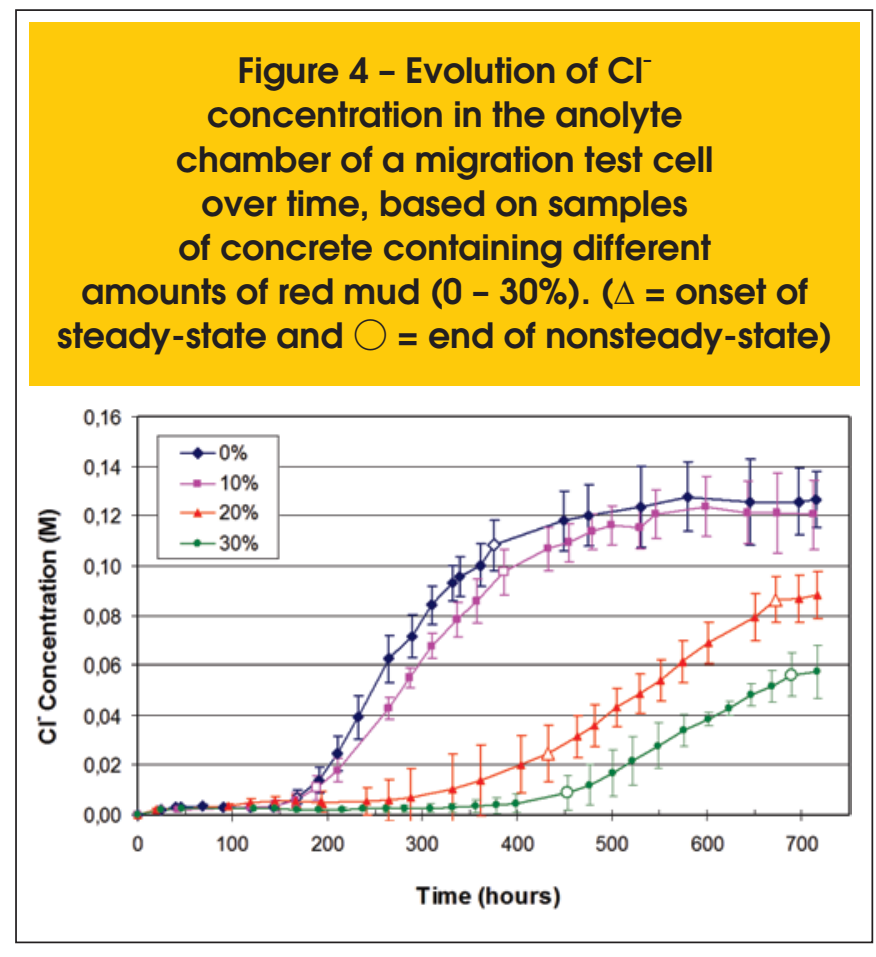

Figure 5 - Experimental determination of the time lag $(\tau)$; onset $(\Delta)$ and end $(\bigcirc)$ of the steady-state diffusion stage, with a diffusion coefficient of $D_{s}$

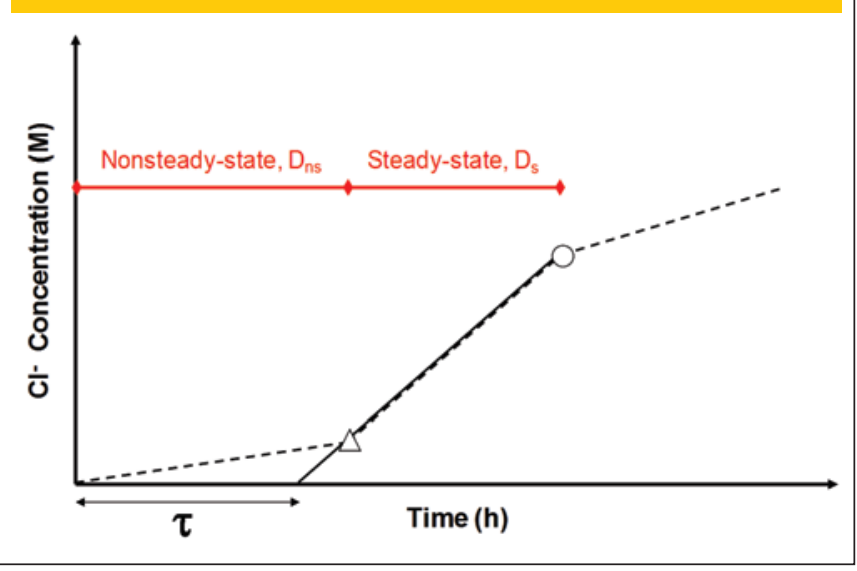




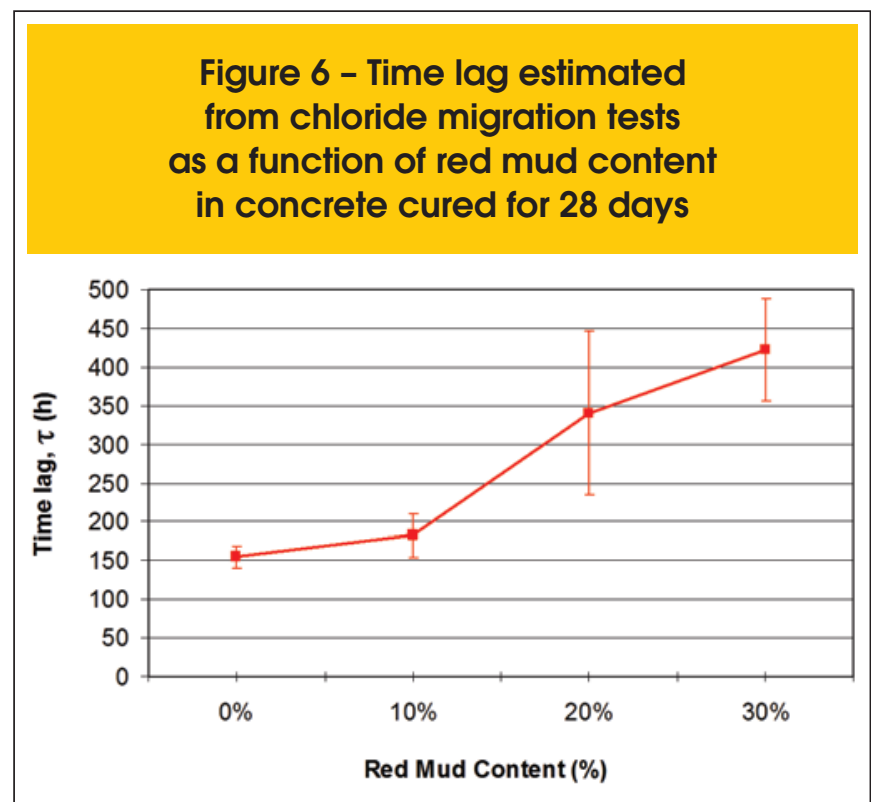

The "time lag" is empirically obtained from the intersection between the extension of the line that characterizes the steady-state and the time axis, according to the diagram of Figure 5.

Figure 6 shows that the "time lag" increases with increasing waste content, probably due to the reduction of a relative number of capillary pores [19]. Moreover, the mud particles may close or interrupt the connectivity between some of those pores, thus diminishing the capillary suction of the concrete and hindering the transport of substances [20]. This occurs even in samples showing higher total porosity, meaning that within certain limits this parameter is not relevant.

After the time lag, the flux of chloride ions through the specimen increases at a constant rate, which corresponds to the steady-state regime [16]. The steady-state diffusion coefficient $\left(D_{s}\right)$ in migration tests is estimated using the Modified Nernst-Planck equation:

$$
D_{S}=\frac{J_{C l} R T l}{z F C_{C l} \gamma \Delta \Phi}
$$

where: $D_{s}=$ steady-state diffusion coefficient; $J_{C I}=$ flux of chloride ions $\left(\mathrm{mol} / \mathrm{cm}^{2} . \mathrm{s}\right) ; \mathrm{R}=$ gas constant $(1.9872 \mathrm{cal} / \mathrm{mol} . \mathrm{K}) ; \mathrm{T}=$ temperature $(\mathrm{K}) ; \mathrm{I}=$ sample thickness $(4 \mathrm{~cm}) ; \mathrm{z}=$ ion valence (chlorides $=1$ ); $\mathrm{F}=$ Faraday's constant $(23063 \mathrm{cal} / \mathrm{volt} . \mathrm{eq}) ; \mathrm{C}_{\mathrm{cl}}=$ chlorides concentration in the catholyte $\left(\mathrm{mol} / \mathrm{cm}^{3}\right) ; \mathrm{g}=$ activity coefficient of the catholyte solution $\left(\mathrm{Cl}^{-}=0.657\right)$ and $\Delta \Phi=$ effective applied voltage (12V). The chloride ion flux $\left(\mathrm{J}_{\mathrm{Cl}}\right)$ represents the speed at which the ions are transported through the concrete, and the steady-state and nonsteady-state diffusion coefficients are calculated based on this flux. The chloride ion flux can be calculated using the linear slope, between the start and the end of steady-state diffusion on the graph representing the evolution of the chloride concentration in the anodic cell as a function of time (see Figure 5):

$$
J_{C l}=\frac{V}{A} \cdot \frac{d C}{d t}
$$

where, $\mathrm{A}=$ exposed area $\left(\mathrm{cm}^{2}\right) ; \mathrm{V}=$ volume of the cathodic chamber $\left(\mathrm{cm}^{3}\right)$ and; $\mathrm{dC} / \mathrm{dt}=$ linear slope of steady-state diffusion, on the graph of chloride concentration as a function of time.

The time that chlorides would require under natural conditions of diffusion to reach the penetration depth observed in migration tests, $t_{\text {dif }}$, is calculated according to Equations $(B)$ and $(C)$, proposed by CASTELLOTE et al. [16].

$\frac{1}{t_{\text {dif }}}=\frac{6}{\tau v^{2}} \cdot\left[v \cdot \operatorname{coth} \frac{v}{2}-2\right]$
$v=\frac{z e \Delta \Phi}{k T}$

where: $\mathrm{t}=$ time-lag in the migration test; $\mathrm{t}_{\text {dif }}=$ time equivalent of diffusion (s); e = electron charge $\left(1.610^{-19} \mathrm{C}\right) ; \mathrm{k}=$ Boltzmann's constant $\left(1.3810^{-23} \mathrm{~J} / \mathrm{K}\right)$.

This mathematical solution allows migration tests to be "converted" into natural tests. In other words, using this "equivalent" time $\left(t_{\text {dif }}\right)$, $D_{n s}$ is obtained directly from Equation (D):

$$
D_{n s}=\frac{l^{2}}{3 t_{d i f}}
$$

where: I = specimen thickness $(\mathrm{cm})$.

Figure 7 shows the flow of chloride ions, $\mathrm{J}_{\mathrm{C}}$, through the concrete as a function of red mud content in the material. This parameter represents the speed at which the ions are transported through the concrete and from which the steady-state and non-

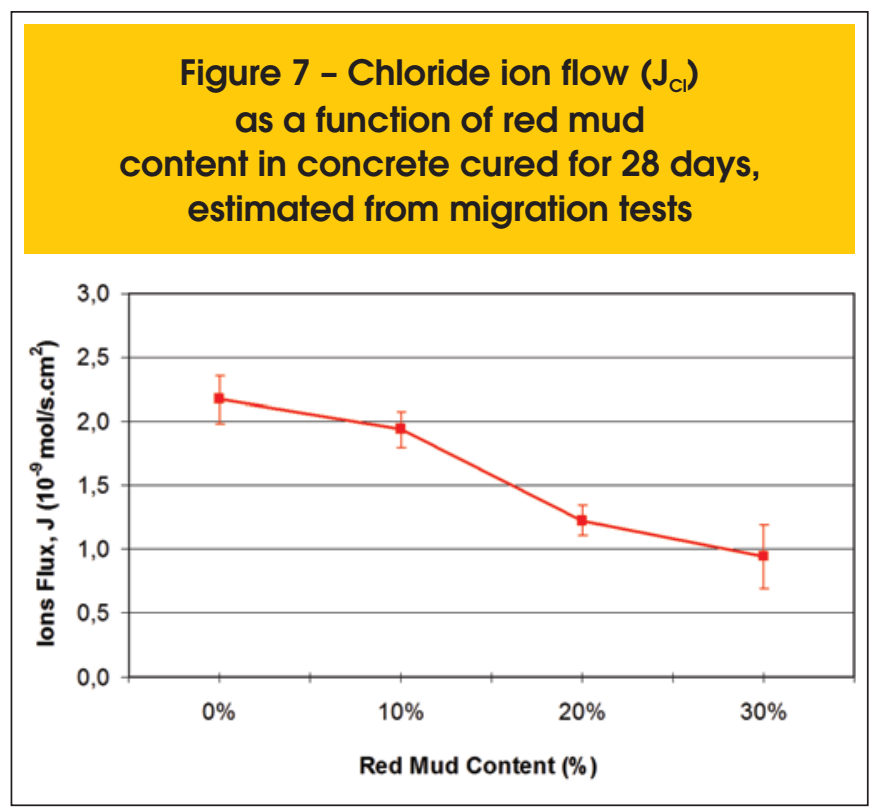




\section{Figure 8 - Steady-state and nonsteady-state diffusion coefficients of chloride ions as a function of red mud content in concretes cured for $\mathbf{2 8}$ days, estimated from migration tests}

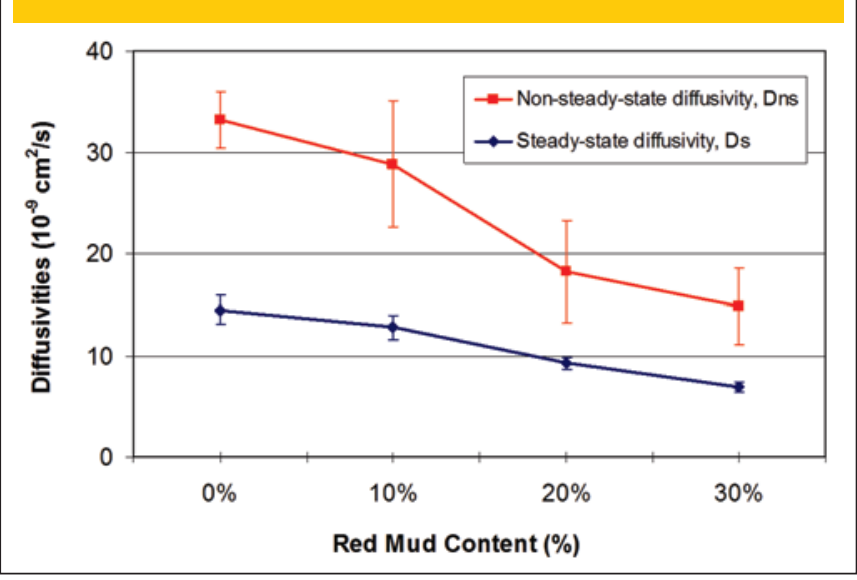

steady-state diffusion coefficients (Figure 8) are calculated. A clear decrease in the flow of chloride ions is observed in samples containing increasing amounts of waste. This is very positive because it reveals a delay in the onset of the corrosion process caused by the migration of chloride ions. These observations are in agreement with findings reported SANTOS [18] e AIITCIN [21], who showed the tendency of supplementary cementitious materials (such as red mud) to significantly reduce the mobility of chloride ions, reflecting the effect of increased tortuosity and better pore diameter distribution resulting from the pozzolanic reactions, which hinder ionic movement.

Moreover, red mud contains mineralogical phases such as sodium aluminosilicates, known as sodalites, i.e., zeolite-type compounds with an extremely high ion-exchange capacity, which makes red mud a good absorber of heavy metals [22] and influences their surface properties [23], including the formation of compounds by reaction with chloride ions. Other authors [24] also cite the importance of the presence of aluminates, which play an important role in anchoring the chloride ions, which would otherwise be free and available to start the corrosion process.

The aspects discussed in the above paragraph are also reflected in the steady-state and nonsteady-state diffusion coefficients of chloride ions shown in Figure 8, both of which decreased due to the addition of a higher red mud content.

Some authors $[16,18,25]$ attribute reductions of the diffusion coefficient to reductions in the water/binder (in this case, cement + red mud). However, they report a decrease in total porosity as this ratio diminishes, which was not the case in the present study. Therefore, the results cannot be correlated with a decrease in the water/binder ratio. In an attempt to have more sensitive representations about the benefits of the red mud use, the results of chloride penetration are related with the service life of reinforced concrete. For this purpose, the Fick's second law of diffusion (equations $\mathrm{E}$ and $\mathrm{F}$ ) was used, according to proposed by recent studies [24, 26].

$$
P C=2(z) \sqrt{D_{s} \cdot t}
$$

$$
\operatorname{erf}(z)=1-\frac{C_{c l}-C_{o}}{C_{S}-C_{o}}
$$

where $D_{s}$ is the steady-state diffusion $\left(\mathrm{cm}^{2} /\right.$ year $), t$ is the service life (years), $\operatorname{erf}(z)$ is the Gaussian error function, CP (chloride penetration) is the depth at which the chloride reaches the threshold limit concentration for rebar depassivation $(\mathrm{cm}), \mathrm{C}_{0}$ is the initial chloride concentration (in this case, $0 \%$ ), $\mathrm{C}_{\mathrm{s}}$ is the chloride concentration at the surface $(\%)$, and $\mathrm{C}_{\mathrm{Cl}}$ is the chloride concentration as a function of depth and time (\%), by cement mass.

Additionally, in line with the literature [26, 27], several parameters were fixed: $\mathrm{C}_{\mathrm{S}}=1.8 \%$ and $\mathrm{C}_{\mathrm{Cl}}=\mathrm{C}_{\mathrm{dep}}=0.4 \%$ per weight of cement, where $\mathrm{C}_{\text {dep }}$ is the chloride threshold limit concentration to depassivate the rebars (per weight of cement). The results obtained are shown in Figure 9, which highlights the service life values for chloride penetration in structures with a concrete layer equal to $4 \mathrm{~cm}$ thick (minimum required by standards for heavy environments, with presence of chlorides). These values are best viewed in Figure 10. The formulation without red mud shows a service life of 16.5 years. As can be seen, the addition of red mud extends the service life of the concrete to up to 35 years (twice the service life of the reference concrete) to specimens containing $30 \mathrm{wt} . \%$ of red mud addition.

\section{Conclusions}

This research led to the following conclusions:

- The time lag increases with increasing red mud content as a result of the reduction in the relative amount of capillary pores;

- The decrease in the interconnectivity between capillary pores in samples containing red mud and the presence of typical mineralogical phases such as sodium aluminosilicates, known as sodalites, are responsible for reducing the flow of

\section{Figure 9 - Correlation between time and depth of chloride penetration in concrete containing different amounts of red mud (to reach $0.4 \% \mathrm{Cl}^{-}$per weight of cement)}

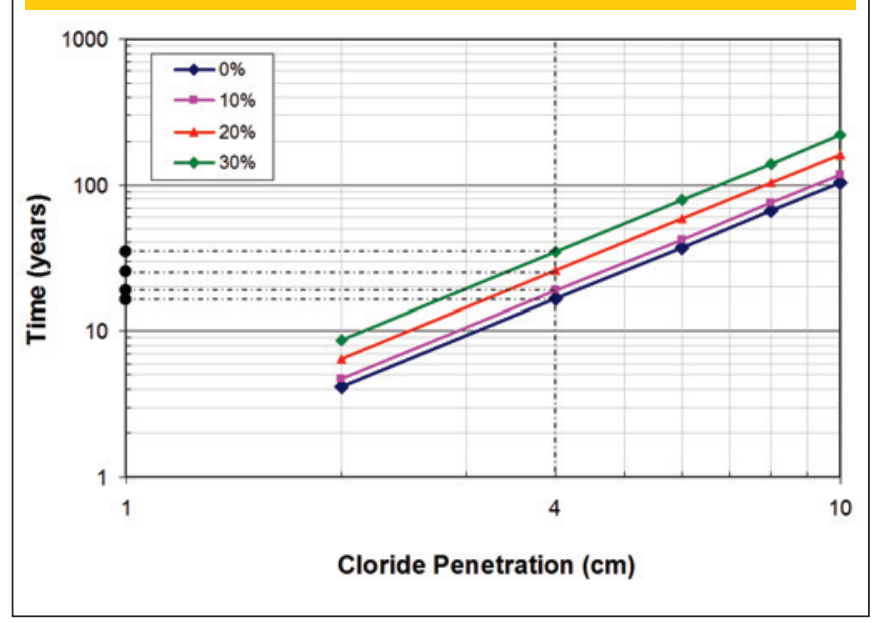




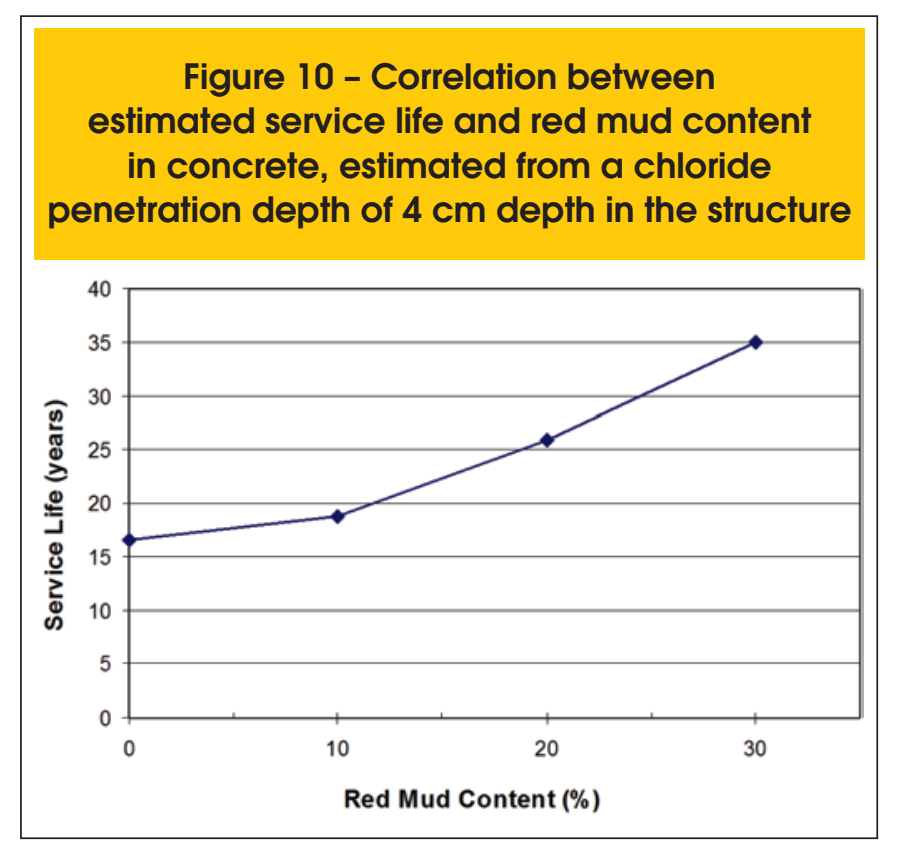

chloride ions, and hence, the steady-state and nonsteadystate diffusion coefficients;

- The chloride migration tests of samples of concrete containing red mud showed a longer service life, reaching more than double that of the reference samples (16.5 versus 35 years).

\section{Acknowledgements}

The authors wish to thank the FAPESB - Bahia Research Foundation, PPGCEM/UFSCar - The Postgraduate Program in Materials Science and Engineering at the Federal University of São Carlos (Brazil) and the UA/DECV - Ceramics and Glass Engineering Dept., University of Aveiro \& CICECO (Portugal) - Project FCTPTDC/CTM/65243/ 2006, for their support of this research.

*This project did not have the financial support of Alcoa Brazil.

\section{References}

[01] ABRELPE - Associação Brasileira de Empresas de Limpeza Pública e Resíduos Especiais. PANORAMA DOS RESÍDUOS SÓLIDOS NO BRASIL 2009. Abrelpe, 2009. $210 \mathrm{p}$.

[02] IBRAM - Brazilian Mining Association. Bauxita. Available in: <www.ibram.org.br/sites/1300/1382/00000033.pdf> Accessed in oct., 15th, 2010.

[03] ROSKILL REPORTS. The Economics of Bauxite \& Alumina. Available in: <www.roskill.co.uk/index.html $>$. Accessed in nov., 20th, 2010.

[04] SINGH, M.; UPADHAYAY, S.N.; PRASAD, P.M. Preparation of special cements from red mud. Waste Management, v. 16, n. 8, p. 665-670, 1996

[05] GLASSER, F.P. Fundamental aspects of cement solidification and stabilization. Journal of Hazardous Material, v. 52: p. 151-170, 1997.

[06] AMRITPHALE, S.S. et al. A novel process for making radiopaque materials using bauxite- - Red mud. Journal of the European Ceramic Society. v. 27, n. 4, p. 1945-1951, 2007.

[07] AMRITPHALE, S.S.; PATEL, M. Utilisation of red mud, fly ash for manufacturing bricks with pyrophyllite. Silicates Ind, v. 2, n. 3, p. 31-35, 1987.

[08] VINCENZO, M.S.; RENZ, C.; STEFANO, M.; GIOVANNI, C. Bauxite red mud in the ceramic industry. Part 2: production of clay based ceramics. Journal of the European Ceramic, v. 20, n. 3, p. 245-252, 2000.

[09] YALCIN, N.; SEVNIC, V. Utilization of bauxite waste in ceramic glazes. Ceramics International, v. 26, n. 5, p. 485-493, 2000.

[10] ASOKAN, P.; SAXEAN, M.; ASOLEKAR, S.R. Coal combustion residues-environmental implications and recycling potentials. Resources, Conservation and Recycling, v. 43, n. 3, p. 239-262, 2005.

[11] TSAKIRIDIS, P.E.; AGATZINI-LEONARDOU, S.; OUSTADAKIS, P. Red mud addition in the raw meal for the production of Portland cement clinker. Journal of Hazardous Material, v. 116, n. 1-2, p. 103-110, 2004.

[12] SINGH, M.; UPADHAYAY, S.N.; PRASAD, P.M. Preparation of iron rich cement from red mud. Cement and Concrete Research, v. 27, n. 7, p. 1037-1046, 1997.

[13] CABEZA, et al. Red mud as a corrosion inhibitor for reinforced concrete. The Journal of Corrosion Science and Engineering, v. 6, n. 32, p. 1-4, 2003.

[14] GORDON, J.N.; PINNOCK, W.R.; MOORE, M.M. A preliminary investigation of strength development in Jamaican red mud Composites. Cement and Concrete Composites, v. 18, n. 6, p. 371-379, 1996.

[15] ANDRADE, C. Calculation of diffusion coefficients in concrete from ionic migration measurements. Cement and Concrete Research, v.23, n. 3, p. 724-742, 1993.

[16] CASTELLOTE, M.; ANDRADE, C.; ALONSO, C. Measurement of the steady and non-steady-state chloride diffusion coefficients in a migration test by means of monitoring the conductivity in the anolyte chamber. Comparison with natural diffusion tests. Cement and Concrete Research, v.31, n. 10, p. 1411-1420, 2001.

[17] TONG, L.; GJøRV, O.E. Chloride diffusivity based on migration testing. Cement and Concrete Research. v.31, n. 7, p. 973-982, 2001.

[18] SANTOS, L. Avaliação da resistividade elétrica do concreto como parâmetro para a previsão da iniciação da corrosão induzida por cloretos em estruturas de concreto. 161p. Dissertação (Mestrado em estruturas), Departamento de Estruturas, Universidade de Brasília, Brasília, 2006.

[19] RIBEIRO, D.V.; LABRINCHA, J.A.; MORELLI, M.R. Use of Red Mud as Addition for Portland Cement Mortars. Journal of Materials Science and Engineering, v. 4, n. 8, p. 1-9, 2010.

[20] SONG, G. Equivalent circuit model for SAC electrochemical impedance spectroscopy of concrete. Cement and Concrete Research, v. 30, n.11, p. 1723-1730, 2000.

[21] AIITCIN, P.C. The durability characteristics of high performance concrete: a review. Cement and Concrete Composites, v. 25, n. 4-5, p. 409-420, 2003.

[22] CHVEDOV, D.; OSTAP, S.; LE, T. Surface properties of red mud particles from potentiometric titration. Colloids Surface A, v. 182, n. 1, p. 131-141, 2001.

[23] LOPEZ, E.; SOTO, B.; ARIAS, M. Adsorbent properties 
of red mud and its use for wastewater treatment. Water Research, v. 32, n. 4, p. 1314-1322, 1998.

[24] YADAV, V.S.; et al. Sequestration of carbon dioxide (CO2) using red mud. Journal of Hazardous Materials, v. 176 n. 1-3, p. 1044-1050, 2010.

[25] AMPADU, K.O.; TORII, K.; KAWAMURA M. Beneficial effect of fly ash on chloride diffusivity of hardened cement paste. Cement and Concrete Research, v. 29, n. 4, p. 585-590, 1999.

[26] MEDEIROS, M.H.F.; HELENE, P. Surface treatment of reinforced concrete in marine environment: Influence on chloride diffusion coefficient and capillary water absorption. Construction and Building Materials, v. 23, n. 3,

p. 1476-1484, 2009.

[27] NILSSON, L.; ANDERSEN, A.; LUPING, T.; UTGENANNT, $P$. Chloride ingress data from field exposure in a Swedish road environment. In: SECOND INTERNATIONAL RILEM WORKSHOP ON TESTING AND MODELLING THE CHLORIDE INGRESS INTO CONCRETE, 2000, Paris. Anais... Paris: 2000, 12p. 